\title{
DEMOGRAPHY-BASED DEVELOPMENT: THE CHALLENGES OF CIVIL REGISTRATION TO REDUCE POVERTY IN INDONESIA
}

\author{
Dona Budi Kharisma, Sri Wahyuningsih Yulianti \\ Faculty of Law, Universitas Sebelas Maret \\ E-mail : donabudikharisma@staff.uns.ac.id
}

\begin{abstract}
The present study seeks to analyze the functions of civil registration in poverty reduction and to identify various problems encountered in civil registration in Indonesia. This study was conducted by using an empirical law research. Primary data and legal materials are analyzed qualitatively with empirical juridical approach. The results conclude that civil registration yields demographic data that play a strategic role in the utilization of public services and development planning. Improving the quality of human life, either in the field of education, health or revenue requires demographic data as the policy focus. This gives implications that the basis of development program interventions in the three sectors refer to the aforementioned demographic data. Therefore, the use of demographic data and expansion of the coverage of ownership of demographic documents present as strategic steps for poverty reduction. However, the low attainment of document ownership in some regions and the limited number of civil registration apparatuses become an indicator of the absence of roles of demographic data in development. This has an impact on improperly targeted development planning. Several strategies that need to be implemented include: (1) Strengthening regulations at the regional level that regulate the utilization of demographic data in development planning; (2) establishing study program of civil registration law as an attempt of population-based development in Indonesia.
\end{abstract}

Keywords: civil registration, development, poverty

\section{A. INTRODUCTION}

Demographic administration is a series of activities of document structuring and controlling in the issuance of documents and demographic data through population registration, civil registration, information management of demographic administration, and utilization of the results for public services and other sectors development (Article 1 section (1) of Law No. 24 of 2013 on Demographic Administration). It can be concluded from the definition that demographic administration is a tool for a state to find out such demographic events as births, marriages, divorces, deaths and others (for example population records of transfer of domicile). In addition, demographic database available in a demographic administration system of a state can be used for national development planning (National 
Development Planning Agency (Bappenas—Badan Perencanaan Pembangunan Nasional), 2013: 1).

Ben Oppenheim and Brenna Marea Powell in their research point out " In many contexts such documentary proof is necessary to access basic social services such as education, health care and social welfare benefits. In such cases, access to documentation is likely to be associated with improved development outcomes" (Ben Oppenheim and Brenna Marea Powell, 2015: 11). This means that the document of identity or legal identity is a key component of sustainable development goal (SDG). In many contexts, the population documents are required to access basic social services such as education, health, and social welfare. In Kenya, for example, population documents are very useful for better development planning.

Demographic data users, especially planners, and policymakers really need annual demographic data. Unfortunately, due to imperfect scope of records of another demographic data source (population registration), such data have not been maximally used for development planning. Almost all development plans should be supported by data of population number, distribution, and structure according to population age groups relevant to the plans. demographic database is used to provide public services such as the right to vote, access to health services, education, poverty reduction, etc.

However, problems arising in demographic data make demographic administration the center of attention. The non-use of demographic data in development planning and the low coverage of ownership of demographic documents exert an influence on nonoptimal utilization of demographic data for public services and development planning, especially for improvement of the quality of life in fields of education, health and poverty reduction. Reformation of the structuring of demographic administration that was once underestimated is now highly required. Therefore, it is necessary to study challenges encountered by the local government in organizing the demographic administration. Based on the results of the study, it can be recommended that demographic documents can play a role in poverty reduction in Indonesia. 


\section{B. PROBLEM STATEMENT}

Based on the problem the writer has elaborated above, the problems studied in the article is how identify, analyze and describe the challenges of civil registrasion in poverty reduction in Indonesia

\section{RESEARCH METHODS}

The present research belongs to law research, particularly empirical law research. In this case, the law is interpreted as a reality. The research locations include the Ministry of Internal Affairs' General Directorate of Population and Civil Registration of the Republic of Indonesia, Department of Population and Civil Registration of Surakarta, Department of Population and Civil Registration of Sukoharjo, Department of Population and Civil Registration of Boyolali, Department of Population and Civil Registration of Sragen, Department of Population and Civil Registration of Karanganyar and Department of Population and Civil Registration of Wonogiri. Instruments of data collection used are structured interview and observation supported by literary data, as well as field research in the form of interviews with respondents. In addition, the research emphasizes on legal science and focuses on secondary data collection comprising primary, secondary, and tertiary legal materials. (Soerjono Soekanto and Sri Mamudji, 14-15).

The primary legal materials involve statutory laws concerning civil registration and demographic administration, while secondary law materials include legal opinions/doctrines/theories derived from legal literature, research results, and scientific articles. The research is descriptive, aiming at describing characters of populations and certain factors in systematic, factual, and accurate way. This research describes strategic roles of demographic data in poverty reduction and identifies various problems encountered in civil registration in Indonesia. After all of the problems had been identified, several strategies were recommended to include demographic data in development planning and policy formulation. Data were analyzed using qualitative juridical analysis, an analysis based on the interpretation of law, the reasoning of law, and the argumentation of law. Some of the juridical references used in this study are Law of the Republic of Indonesia No. 24 of 2013 
regarding Amendment to Law No. 23 of 2006 concerning Demographic administration, and other civil registration-related laws and regulations.

\section{DISCUSSION AND THE RESEARCH RESULTS}

1. The Strategic Roles of Demographic Data in Poverty Reduction

Demographic data is a tool for a state to find out demographic events and other vital events which lead to legal status of the citizens. Demographic events include resettlement, change of address, and change of residence permit from limited to permanent (Article 1 section 11 of Law No. 24 of 2013). Meanwhile, vital events include births, deaths, stillbirths, marriages, divorces, recognition of a child, legitimation of a child, adoption, change of name, and change of citizenship status (Article 1 section 17 of Law No.24 of 2013). It is inseparable from the meaning of demographic data, structured individual or aggregate data as a result of civil registration activities such as births, marriages, divorces, deaths, and others (for example population records of transfer of domicile). (Article 1 section (9) of Law No. 24 of 2013).

However, in addition to finding out demographic events and vital events that can lead to a person's legal status, demographic data play strategic roles for policy formulation in the field of governance and development (Article 83 section (1) of Law No. 24 of 2013). Such policy is implemented to allow government to easily know and manage the condition of the people in Indonesia. Demographic data are very important thing in the life of society today.

Demographic data refer to data containing all vital events experienced by an individual, describing the condition of the surrounding population. They are useful to figure out size and composition of the population, by category of age, sex, residence area, for government to make policies in order to improve national development.

In developing countries, demographic data play a strategic role as a strategy in development planning of a state. Developing countries require demographic data for national development planning, implementation, and evaluation of the planning and implementation.

In many contexts, such documentary proof is necessary to access basic social services such as education, health care and social welfare benefits. In such cases, access to 
documentation is likely to be associated with improved development outcomes (Ben Oppenheim \& Brenna Marea Powell, 2015: 11). Results of a research conducted by Ben Oppenheim and Brenna Marea Powell confirm that a demographic document or legal identity is a key component of Sustainable Development Goals (SDGs). In many contexts, a demographic document is required to access basic social services such as education, health and social welfare. In Kenya, a demographic document is used extensively for state development planning.

The demographic data of a country contain all the important in for planning and for the rendering of services, as input factor for decision in the day-to-day administration, formulation of policies, allocation of resources, policy implementation and the monitoring of government programs (Onofere Princewill, 2015: 36). In Nigeria, demographic data contain all of important demographic data related to planning and service. They serve as suggestions to make a decision in government, policy formulation, resource allocation, implementation policy and monitoring of government programs. It is certain that a country with no demographic data support is unable to develop itself.

The use of demographic data by the Ministry of Internal Affairs sourced from demographic data of regency/city can be used for several purposes, as explained below:

1. Budget allocation, for example in determining General Allocation Fund (DAU_Dana Alokasi Umum) and calculating taxation potential.

2. Public services, for example, Electronic ID card services (E ID card is required for prerequisite of Driver's License (SIM-Surat Izin Mengemudi), Business Trade License (SIUP_Surat Izin Usaha Perdagangan) services, taxpayer services, banking services, and issuance services of certificate of title.

3. Development planning, among others for national development planning, education planning, economic planning, health planning, manpower planning, provision of public facilities and infrastructure.

4. Development of democracy, which involves preparation of Population Aggregate Data by Subdistrict (DAK2-Data Agregat Kependudukan per Kecamatan) and preparation of Data of Voting Eligible Population (DP4Data Penduduk Potensial Pemilih Pemilu). 
5. Law enforcement and crime prevention, for example the tracking of perpetrators of crime, prevention of human trafficking, prevention of illegal workers, etc.

In the context of poverty reduction, the government is currently making a policy through infrastructure improvement, human development, and economic development. Particularly in human development sectors, the accuracy of demographic data plays an important role in enhancing policy focus. Each policy in fields of education, health, and income as a component of the Human Development Index (HDI) uses demographic data as the basis for goal setting. According to The United Nations Economic and Social Commission for Asia and the Pacific (UNESCAP), demographic data raise visibility and enhance policy focus on vulnerable groups or populations such as women and children in poverty and disease, and immigrant groups. (Matangi Evidence, Mhlangwa Adwell, et al., 2012: 82-89).

In term of education, the government is currently making a policy, namely Indonesia Pintar by creating the Indonesia Smart Card (KIP-Kartu Indonesia Pintar), which can be used for Indonesian children of poor family (www.indonesiapintar.kemdikbud.go.id). Also, the government provides scholarships and develops educational facilities and infrastructure. Demographic data are needed to determine those who deserve educational support.

In term of health, the government has also initiated the program of National Health Insurance - Indonesia Health Card (JKN/Jaminan Kesehatan Nasional - KIS/Kartu Indonesia Sehat), which categorizes participants into Contribution Assistance Recipients and Non-Contribution Assistance Recipients. The former include poor people whose health insurance contributions are borne by central government and local governments. (www.jkn.kemkes.go.id). In addition, in relation to health efforts, prior to vaccination for population, government should take real-life conditions into account to ensure that vaccination is on target. Improvement of health services, such as by building hospitals and/or public health center as centers of public health services, also requires demographic data.

In addition, a study by Bio Med Central Public Health in Africa indicates that population registration and recording of vital events could be used to monitor population and community health levels. "Vital statistics are used to monitor levels and trends in the 
fields of population, public health, and administrative planning for public health decisionmakers and policy promulgators to be effective. The data collected by CRVSs can also be used to monitor and evaluate the impact of any public health initiative that has been undertaken by governing bodies to improve the quality of health in their communities“" (Yazoume Ye, Marilyn Wamukoya, et al.,: 2012). In formulating a policy in the field of health, government requires accurate and complete data of all vital recordings of vital events of society to make decisions effective and on target. In addition, the recorded data can be used to monitor and evaluate the impact of public health policies to improve the quality of public health in South Africa.

In term of revenue, government has developed a policy related to improvement of competitiveness, public purchasing power, investment, exports, tourism, and economic growth. Government gives an ease in establishing a business and open simple and quick access to credit for applicants. Demographic data are needed when society proposes business license, or accesses bank credit.

Accurate and valid data related to demographic data are highly needed to achieve on government's on target attempts to improve human development through education, health, and revenue. Therefore, realizing sustainable poverty reduction requires demographic data. Demographic data play an important role as the basis and consideration of government in making policies. If population has registered through demographic administration, then demographic data will be processed and used as a guide to determine the policy focus. Then, government will follow up the existing demographic data, and therefore the government can issue a solutive targeted policy.

\section{Challenges Encountered by Government in Implementing Demographic administration}

Demographic administration organized from center to region is a breakthrough by government in development planning. With demographic data, government has a database to improve human development, especially to overcome poverty. In addition to being useful for development planning, the demographic administration provides more actual, faster and more inexpensive data compared to population census.

A research conducted by B. Guy Peters of the University of Pittsburgh points out, "The continuous nature of the data collection through civil registration provides a more 
up-to-date and less expensive means of addressing the need for population information than a population census performed once a decade, providing a better ongoing picture of movements in society“ (B. Guy Peters, 2016: 8). Continuous and up-to-date data of demographic information through registration and civil registration are very useful and at a much cheaper cost than the population census conducted every decade, providing information on population movements in the society.

The more the population number is, the more the affairs that must be done by government in human development will be. It is known that Indonesia is a developing country that has a large population after China, India and the United States (republika.co.id, 2017). On the one hand, government's attempts to improve human development through education, health, and income require demographic data to make targeted decisions. Therefore, the increasing quantity of population in Indonesia signifies the importance of demographic data.

However, in the implementation of demographic administration, especially in civil registration, several challenges should be encountered government. The first challenge is low coverage of ownership of residence documents. It gives consequences on the absence of contribution of demographic data in development planning. For example, in Central Java, based on data of the Ministry of Internal Affairs' General Directorate of Population and Civil Registration of the Republic of Indonesia, there are still some areas in Central Java of which percentage of attainment of demographic documents is still far below the minimum target achievement of $80 \%$. In Solo Raya, for example, the highest coverage of document ownership is in Surakarta City with $88.95 \%$ achievement rate, followed by Sragen regency (87.34\%), Wonogiri regency (83.35\%), Karanganyar regency (72.40\%), Boyolai regency (63.69\%), Klaten regency (61.97\%) and Sukoharjo regency (40.82\%) (Data of Demographic Administration Information System by June 2016).

In addition, the low level of public awareness and the lack of knowledge of the use of demographic documents are factors causing the low coverage of ownership of public residence documents. Poni Sukaesih stated that "One of the most important things to do is to understand the importance of humanity, factory workers are not easy to devote time to participate following data recording process of e-ID card. Apart from the problem of active communities as workers, elderly, physically disabled, recapitulation e-ID bulk e- 
ID card recording has not been entirely successful. The existence of people who do not receive the e-ID card is also an awareness of the problems related to the changes of the conventional ID cards to electronic ID cards" (Poni Sukaesih, 2015: 35).

Secondly, the challenges are related to Human Resource of civil registration. In addition to the limited number of civil registration apparatuses, the lack of knowledge and skills of officers in understanding the laws, conceptions, requirements, and mechanisms of civil registration are also included as challenges that must be encountered by government. On the one hand, Law No. 24 of 2013 on Demographic Administration mandates public demographic administration services using government's active stelsel. Such system demands government's active roles through civil registration officers' one day service or mobile services. The law also mandates local government to establish Technical Implementation Unit (UPTD-Unit Pelaksana Teknis Dinas) in each subdistrict and appoint a registration officer in each village or hamlet whose special task is to manage demographic administration in the area.

The use of active stelsel requires the availability of resources of civil registration apparatuses in regions with adequate legal and technical skills. However, the limited number of civil registration apparatuses becomes a constraint in implementation of demographic administration. This can be clearly seen in the analysis of the needs of civil registration officers in Indonesia. According to Joko Mursito, Director of Ministry of Internal Affairs' Development of Population and Civil Registration Apparatuses, the 2016 analysis of the needs of civil registration officers in Indonesia, considering the number of regencies/ districts and provinces reaching 3,196 people is outlined in the following table:

\begin{tabular}{|c|c|c|c|c|c|c|}
\hline \multicolumn{2}{|c|}{ Regency } & \multicolumn{2}{|c|}{ Province } & \multicolumn{2}{|c|}{ Center } & Annotation \\
\hline JFU & PP & JFU & PP & JFU & PP & \\
\hline $\begin{array}{r}4 \times 514 \\
=\mathbf{2 , 0 5 6}\end{array}$ & $\begin{array}{l}2 \times 514 \\
=\mathbf{1 , 0 2 8}\end{array}$ & $\begin{array}{c}2 \times 34 \\
=68\end{array}$ & $\begin{array}{l}1 \times 34 \\
=\mathbf{3 4}\end{array}$ & 10 persons & - & $\begin{array}{l}\text { The data are estimates of } \\
\text { needs of human resources in } \\
2016 \text { with respect to the } \\
\text { number of districts (514) and } \\
\text { provinces (34) in Indonesia. }\end{array}$ \\
\hline $\begin{array}{l}\text { Total Nee } \\
\text { Resource }\end{array}$ & uman & $3,196 \mathrm{p}$ & & & & \\
\hline
\end{tabular}


Annotation:

$\mathrm{JFU} \quad=$ General Functional Position

$\mathrm{PP} \quad=$ Supervisory Officers

Public Policy Observer at Universitas Indonesia, Lisman Manurung said that the capability of a region in responding to central government policy depends on the availability and quality of human resources. Lisman Manurung referred to the birth certificate record in Deiyai district of Papua province, which is only 0.03 percent. (Jawa Pos, March 7, 2016). It can be concluded that the problems of civil registration human resources are closely related to the high/ low coverage of demographic documents. Therefore, civil registration human resources become a serious problem that needs to be immediately solved.

\section{Strategies of the Government of Indonesia in the Implementation of Demographic}

\section{Administration}

In improving the quality of human life, either in the field of education, health, or income, government should always make use of demographic data as a focus for policy making. This will give implications on the basis of development program interventions in those three sectors referring to the intended demographic data. Therefore, the use of demographic data and expanding the coverage of ownership of population documents is a strategic step for poverty reduction.

However, the low attainment of demographic document ownership in some areas and the limited number civil registration apparatuses lead to the absence of functions of demographic data in development. This may exert an influence on improperly targeted development planning because it is not in accordance with the real conditions and needs of the society.

The first strategy that can be done to overcome the problems above is strengthening regulations especially at the regional level regarding the utilization of demographic data in development planning. The regional regulation governs not only the implementation of local demographic administration, but also the utilization of demographic data in development planning. The regulation serves as a guideline for the utilization of demographic data based on single identity number in local development planning program. Aside from being a guideline, the regulation also manages the coordination of cross sectors in the utilization of demographic data. It aims to realize a 
system of utilization of single identity number-based demographic data to encourage local development planning program to enhance national society wellbeing.

Government of the Republic of Rwanda copes with several problems of demographic administration by "enabling legal and policy environments, high level coordination and fix oversight mechanisms, management or organizing institutions, database management" (National Institute of Statistics of the Republic of Rwanda, 2016: 45). This means that strengthening the regulations or policies which regulate the improvement of coordination, monitoring mechanisms, management or organization, and database management is essential to do.

For example, the utilization of demographic data in Surakarta city as an attempt to reduce poverty has a legal umbrella: Mayor's Regulation No. 16 of 2015 REGARDING the Utilization of Single Number Identity-based Demographic data for Development Planning in Surakarta city. In the efforts to reduce poverty, the local government of Surakarta involves all sectors consisting of Regional Development Planning Agency, Department of Social Services, Department of Communications and Informatics, Department of Population and Civil Registration, and Poverty Application Team of Surakarta city.

Rita Margareta K. as Head of Management of Information of Demographic Administration (PIAK-Pengelolaan Infomasi Administrasi Kependudukan) Department of Population and Civil Registration of Surakarta stated that the demographic data at the Department of Population and Civil Registration of Surakarta city has been utilized by online E-Gakin application (Surakarta Poverty System Application). E-Gakin accessed more than 32,384 data a day. In addition, Department of Population and Civil Registration of Surakarta also established a Team or Desk specifically to verify the demographic data accessed by the E-Gakin application.

The existence of local regulations regarding the utilization of demographic data can be a guideline as well as legal basis for every stakeholder of region, private, and society in regional development planning program. Thus, each stakeholder will have an accurate, centralized, and integrated database of development, resulting in an appropriate, actual, qualified, and accountable poverty reduction policy analysis. In addition, every population-based poverty reduction program will result in measurable and comprehensive 
development planning and realize effective development control, reliable monitoring, evaluation and reporting of development; through accurate, up to date, integrated, complete, accountable, dynamic, accessible and sustainable data management.

The second strategy is increasing the number and competence of civil registration apparatuses that understand laws, conceptions, requirements and mechanisms of civil registration through special education majoring in civil registration law. Law No. 24 of 2013 on Demographic Administration which mandates demographic administration services to public using the government's active stelsel emphasizes vital roles of civil registration apparatuses.

The limited number of civil registration apparatuses, lack of knowledge and skills of the apparatuses in understanding laws, conceptions, requirements and mechanisms of civil registration also presents as a problem in conducting local demographic administration. Soewarno Handayaningrat (1995: 154) points out that that an apparatus is an administrative aspect required in the administration of state/government and serves as a tool to achieve national goals. In other words, civil registration apparatus acts as a tool to achieve the goal of organizing demographic administration. Thus, efforts are needed to make to increase the number and competence of civil registration apparatuses.

JB Kristiadi in his book entitled "The Role of Government Apparatus in Development Era" states that to know the ability of government apparatuses, several factors to be considered include:

1. The ratio of the number of employees to the population

2. Work experience

3. Personnel classification

4. Formal education achieved

5. Non-formal education

6. Conformity between education and position (Kristiadi, 1991: 94)

Based on the concept of JB Kristiadi above, to find out the ability of government apparatuses, formal education becomes one factor in improving performance. It can be argued that efforts to increase the number of civil registration apparatuses and to improve their competence of knowledge and skills in understanding laws, conceptions, requirements, and mechanisms of civil registration can be made through formal education. 
The intended formal education is the special education program of civil registration law. In addition to meeting the needs of civil registration apparatuses at the Department of Population and Civil Registration in regencies/ cities, special education in civil registration law aims to equip graduates with the ability to carry out complex work, managerial skills on the basis of professional skills in the field of civil registration, and ability to follow development, knowledge, and technology in their area of expertise.

Strengthening regulation at regional level that governs the utilization of demographic data and the existence of special education of civil registration law are some strategies that can be done by the government as an effort to improve the quality of civil registration service to society and make demographic data as policy focus in every development planning in Indonesia.

\section{E. CLOSING}

\section{CONCLUSION}

1. Demographic data resulted from civil registration process play an important role for development planning and policy formulation, especially in poverty reduction. The data are needed to achieve properly-targeted government's attempts in reducing sustainable poverty through education, health, and revenue.

2. Several challenges encountered by government in civil registration include: (1) The low coverage of ownership of demographic documents, which exerts an influence on the demographic data in the development planning, (2) the limited number of civil registration apparatuses and the lack of their knowledge and skills in understanding laws, conceptions, requirements, and mechanisms of civil registration.

3. Some strategies that can be done to overcome problems in civil registration, involve: (1) Strengthening regulations, especially at the regional level that governs the utilization of demographic data in development planning. The local regulation regulates not only the implementation of demographic administration in regions, but also the utilization of demographic data in development planning; (2) increasing the number and competence of civil registration apparatuses that understand laws, conceptions, requirements and mechanisms of civil registration through special education of demographic studies and civil registration. 


\section{SUGGESTIONS}

1. Ministry of Internal Affairs, in this case, Directorate of Population and Civil Registration of the Republic of Indonesia needs to cooperate with universities to establish demographic and civil registration study programs. In addition to addressing the limited number of civil registration apparatuses, established courses can also be a means of enhancing the competence of civil registration apparatuses that understand laws, conceptions, requirements, and mechanisms of civil registration.

2. Local government, in this case, Department of Population and Civil Registration needs to formulate regulations regarding the utilization of demographic data in poverty reduction. The regulation serves as a guideline as well as a legal umbrella for every stakeholder, private, and community in development planning so as to produce an appropriate, actual, qualified and accountable poverty reduction policy analysis.

3. Central government, in this case, National Development Planning Agency (BappenasBadan Perencanaan Pembangunan Nasional) and Local Government (Regional Development Planning Board (Bappeda-Badan Perencanaan Pembangunan Daerah)) are advised to use demographic data sourced from the Ministry of Internal Affairs' Directorate of Population and Civil Registration as the policy focus in every development planning and policy formulation both at the national level and at the regional level. It is necessary to do so that every policy taken is in accordance with the real data of the community and on target.

\section{BIBLIOGRAPHY}

\section{Books:}

Bappenas (National Development Planning Agency), BPS (Central Bureau of Statistics) \& United Nations Populations Fund, 2013, Proyeksi Penduduk Indonesia 2010-2035 (The 2010-20135 Projection of Indonesian Population), Jakarta: BPS. 
Handayaningrat, Soewarno , 1995, Pengantar Studi Ilmu Administrasi dan Manajemen (Introduction to Administration Science and Management), Jakarta : PT.Toko Gunung Agung.

Kristiadi, J.B. ,1991, Peran Aparatur Pemerintah dalam Era Pembangunan (Roles of Government in Era of Develoment), Bandung: Sesimpol Lembang.

Peters, B.G. (2016), Civil Registration and Vital Statistics as a Tool to Improve Public Management, Inter-American Development Bank, anonimous.

Soekanto, S \& Mamudji, S. ,2006, Penelitian Hukum Normatif (Suatu Tinjauan Singkat) (Normative Legal Research (A Brief Review), First Edition. Jakarta: PT. Raja Grafindo Persada.

\section{Journals:}

Oppenheim, Ben \& Powell, B.M. (October, 2015), "Legal identity in the 2030 agenda for sustainable development: Lessons from Kibera Kenya", Policy Paper, Open Society Foundations, 2015.

Evidence, M., Adwell, M., etc.,"The Challenges in Civil Registration and Improvement amongst Peri-urban Settlers in Harare, Zimbabwe". African Journal of Social Sciences, 2 (4), 2012,

National Institute of Statistics of Republic Rwanda, Africa, "Rwanda Civil Registration and Vital Statistics Systems: Comprehensive assessment final report", anonimous, Volume 1, 2016.

Princewill, O."Vital Civic Registration System as a Tool for Development Planning in Nigeria: An examination of the major Challenges",Journal of Culture, Society and Development, 11., 2015.

Sukaesih, P. , "Policy implementation of electronic identity card (e-ID) in Cimahi city of West Java province of Indonesia”, Journal of International Journal of Science and Research, 4 (2), 2015.

Ye, Y., Wamukoya, M., etc. , "Health and demographic surveillance systems: A step towards full civil registration and vital statistics system in Sub-sahara Africa", Bio Medical Central Public Health, 2012.

\section{Law:}


Law of the Republic of Indonesia Number 24 of 2013 on Amendment to Law Number 23 of 2006 on Demographic Administration (States Gazzette of The Republic of Indonesia Number 244 of 2014)

\section{Newspaper:}

Jawa Pos on March 7, 2016.

\section{Internet:}

http://hdr.undp.org/en/statistics/hdi/ retrieved on February 24, 2017.

Www.indonesiapintar.kemdikbud.go.id, retrieved on July 10, 2017 at 00.17 WIB (Western Indonesian Time).

www.jkn.kemkes.go.id, retrieved on July 10, 2017 at 01.18 WIB (Western Indonesian Time). http://nasional.republika.co.id/berita/nasional/jabodetabek-nasional/13/11/01/mvjx78-bkkbnjumlah-penduduk-indonesia-sangat-tinggi, retrieved on May 30, 2017 at 23.12 WIB (Western Indonesian Time). 